\title{
Transfer rates of pathogenic bacteria during pork processing
}

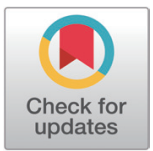

Received: Jun 25, 2020

Revised: Aug 16, 2020

Accepted: Aug 18, 2020

${ }^{*}$ Corresponding author Jin Man Kim

Department of Food Marketing and Safety, Konkuk University, Seoul 05029, Korea.

Tel: +82-2-450-3688

E-mail: jinmkim@konkuk.ac.kr

Copyright (C) 2020 Korean Society of

Animal Sciences and Technology.

This is an Open Access article

distributed under the terms of the

Creative Commons Attribution

Non-Commercial License (http://

creativecommons.org/licenses/by-

nc/4.0/) which permits unrestricted

non-commercial use, distribution, and

reproduction in any medium, provided

the original work is properly cited.

ORCID

Jung min Park

https://orcid.org/0000-0002-8817-2856

Jong Ho Koh

https://orcid.org/0000-0002-9727-8273

Min Joo Cho

https://orcid.org/0000-0002-7530-7686

Jin Man Kim

https://orcid.org/0000-0002-2887-8195

Competing interests

Not applicable.

Funding sources

Not applicable.

Acknowledgements

This study supported by Konkuk

Univesity in 2020.

Availability of data and material

Upon reasonable request, the datasets

of this study can be available from the

corresponding author.

Authors' contributions

Conceptualization: Park Jm, Kim JM.

\author{
Jung min Park ${ }^{1}$, Jong Ho Koh², Min Joo Cho ${ }^{1}$ and Jin Man Kim* \\ ${ }^{1}$ Department of Food Marketing and Safety, Konkuk University, Seoul 05029, Korea \\ ${ }^{2}$ Department of Bio-Food Analysis, Bio-Campus, Korea Polytechnic University, Nonsan 32940, Korea
}

\begin{abstract}
We examined the rates of pathogenic bacterial cross-contamination from gloves to meat and from meat to gloves during pork processing under meat-handling scenarios in transfer rate experiments of inoculated pathogens. The inoculated pork contained $\sim 5-6$ Log $_{10}$ CFU/g pathogenic bacteria like Escherichia coli (E. coli), Staphylococcus aureus (S. aureus), Listeria monocytogenes (L. monocytogenes), and Salmonella enterica subsp. enterica (Sal. enteritidis). On cotton gloves, after cutting the pork, the cutting board, knife, and cotton gloves showed 3.07-3.50, 3.29-3.92 and 4.48-4.86 $\log _{10}$ CFU/g bacteria. However, when using polyethylene gloves, fewer bacteria (3.12-3.75, 3.20-3.33, and 3.07-3.97 $\log _{10}$ CFU/g, respectively) were transferred. When four pathogens ( $\left.6 \mathrm{Log}_{10} \mathrm{CFU} / \mathrm{g}\right)$ were inoculated onto the gloves, polyethylene gloves showed a lower transition rate (cutting board 2.47-3.40, knife 2.01-3.98, and polyethylene glove 2.40-2.98 $\log _{10} \mathrm{CFU} / \mathrm{g}$ ) than cotton gloves. For cotton gloves, these values were 3.46-3.96, 3.37-4.06, and 3.55-4.00 $\log _{10}$ CFU/g, respectively. Use of cotton gloves, polyethylene gloves, knives and cutting boards for up to 10 hours in a meat butchering environment has not exceeded HACCP regulations. However, after $10 \mathrm{~h}$ of use, 3.09, 3.27, and $2.94 \log _{10} \mathrm{CFU} / \mathrm{g}$ of plate count bacteria were detected on the cotton gloves, cutting board, and knives but polyethylene gloves showed no bacterial count. Our results reveal the transfer efficiency of pathogenic bacteria and that gloved hands may act as a transfer route of pathogenic bacteria between meat and hands. The best hand hygiene was achieved when wearing polyethylene gloves. Thus, use of polyethylene rather than cotton gloves reduces cross-contamination during meat processing.
\end{abstract}

Keywords: Transfer rate, Cross-contamination, Meat processing, Glove use, Microbial contamination

\section{INTRODUCTION}

The demand for livestock products is steadily increasing in Korea [1]. Livestock safety management is important because livestock products are easily prone to quality degradation. Concerns regarding meat safety have increased in Korea and worldwide because of changes in the global market; instances of bovine spongiform encephalopathy and foot-and-mouth disease, as well as outbreaks of food poisoning related to meat consumption, have occurred [2]. The major foodborne pathogens in meat include Listeria monocytogenes, Salmonella spp., Escherichia coli, Clostridium botulinum, Staphylococcus aureus, Yersinia enterocolitica, and Campylobacter jejuni $[3,4]$. Concerns regarding meat safety including 
Data curation: Cho MJ. Methodology: Koh JH.

Writing - original draft: Park Jm.

Ethics approval and consent to participate This manuscript does not require IRB/IACUC approval because there are no human and animal participants. meat hygiene, origin, freshness, and taste have become more important than the price of purchase [5]. Pathogen contamination can occur anywhere from the field to the supermarket shelf, with livestock processing serving as a particularly important opportunity for pathogen contamination [6-8]. In livestock-processing plants, possible sources of contamination include air-borne microorganisms, workers' hands, and processing tools such as knives and cutting boards [9]. Microbial cross-contamination of meat products during slaughter can also occur. Cross-contamination plays an important role in transferring harmful pathogens to meat products. For example, mishandling of meat by workers during processing is a significant factor in pathogen outbreaks [10-12]. Particularly, hands may play an important role in contamination [13]. Among raw meat machining in workhouses, microorganisms can be transferred from workers' gloved hands to raw meat, and then continuously to other surfaces contacted by the contaminated gloved hands. As gloved hands are a key route of transferring microorganisms from workers to fresh meat, wearing gloves is an important consideration [14]. Although the importance of preventing cross-contamination is recognized, little is known about cross-contamination between raw meat, working environment, and workers. Particularly, the degree of cross-contamination or contamination transfer in contact with working conditions is not well-understood [15]. Therefore, in this study, we compared and analyzed the contamination transfer rate of four major microorganisms from the hands of workers, and worker tools that frequently come in contact with meat during meat processing, considering the working environment during the processing of packaged meat. Our results provide a foundation for improving the sanitation status of meat processing. Currently, the Hazard Analysis and Critical Control Point (HACCP) system does not have the legal hygiene standards for utensils and recommends only microbiological guidelines for HACCP certification. At butcher shops with HACCP certification, utensils have $5 \log _{10} \mathrm{CFU} / \mathrm{g}$ or less of plate count bacteria and $3 \log _{10} \mathrm{CFU} / \mathrm{g}$ or less of $E$. coli, and meat is certified based on non-detection of Salmonella spp. [16,17]. Our results provide safe standards of establishing a sanitary system in general meat-sales businesses by measuring the status of microbial contamination based on the time of use of utensils (gloves, knives, and cutting boards).

\section{MATERIALS AND METHODS}

\section{Bacterial cultures and isolation conditions}

To study cross-contamination, Escherichia coli (E. coli KCCM 11591), Staphylococcus aureus (S. aureus KCCM 11335), Listeria monocytogenes (L. monocytogenes KCCM 40307), and Salmonella enterica subsp. enterica (Sal. enteritidis, KCCM 12021) were used as representative model pathogens, as the levels of these strains are regulated by the law and are related to meat products [18]. All bacteria were harvested by centrifugation (2,000×g for $10 \mathrm{~min}$ ), washed twice with sterile buffered peptone water (Difco, Detroit, MI, USA), and suspended in buffered peptone water $\left(10^{6}\right.$ colony-forming units $[\mathrm{CFU}] / \mathrm{mL}$ ), which was also used as the diluent in all experiments. E. coli isolates were prepared by overnight incubation $(24 \pm 2 \mathrm{~h})$ in E. coli (EC) broth at $37^{\circ} \mathrm{C}$. S. aureus and Sal. enteritidis were detected by inoculation in Baird Parker broth and XLD (Xylose Lysine Desoxycholate, Difco), respectively, followed by incubation overnight $(18-24 \mathrm{~h})$ at $37^{\circ} \mathrm{C}$. L. monocytogenes isolates were prepared by inoculation into PALCAM broth (Difco), followed by incubation overnight (24-48 h) at $37^{\circ} \mathrm{C}$.

Disinfection process of gloves (cotton and polyethylene), meat, and utensil surfaces Prior to the microbial experiments, sterile gloves (cotton and polyethylene) were placed in a sterile plastic bag until analysis. Meat samples (approximately $25 \mathrm{~g}$ ) were immersed in 70\% ethanol in a $10^{\circ} \mathrm{C}$ incubator for $5 \mathrm{~min}$ to remove the surface microorganisms, followed by sterilization under 
UV light for $1 \mathrm{~h}$ on a clean bench. The cutting board and knife were washed with $2 \mathrm{~mL}$ of antibacterial soap for $30 \mathrm{~s}$, rinsed with distilled water for $15 \mathrm{~s}$, dried with a paper towel, sprayed with 70\% ethanol, and UV-sterilized for $1 \mathrm{~h}$. These procedures served to standardize the initial levels of each pathogen and helped to avoid contaminated final bacterial counts [19].

\section{Initial counts of each pathogen on gloves and meat surfaces}

To determine the initial concentration of bacteria on gloved hands, bacteria suspended $\left(6 \log _{10}\right.$ $\mathrm{CFU} / \mathrm{g})$ in Erlenmeyer flasks were dropped onto one hand $(1 \mathrm{~mL})$ and rubbed with both hands. Each inoculated glove was left in a biological flow hood for $15 \mathrm{~min}$ to facilitate the attachment of bacteria onto the glove surface. The gloves were sampled by squeezing (Seward, London, UK) in $225 \mathrm{~g}$ buffered peptone water for $1 \mathrm{~min}$ and assayed as described in the culture conditions section. Both procedures were repeated three times; bacteria were counted and converted to a mean, which was used as the initial count on each surface. To determine the initial bacterial concentration in the meat samples, the bacterial suspension was inoculated onto the meat surface and allowed to dry $\left(10^{6}\right.$ $\mathrm{CFU} / \mathrm{mL}$ ). Each inoculated piece of meat was left in a biological flow hood for $15 \mathrm{~min}$ to facilitate the attachment of bacteria onto the meat surface. The meat was sampled by crushing in $225 \mathrm{~g}$ buffered peptone water for $1 \mathrm{~min}$ followed by analysis as described in the culture conditions section. Both procedures were repeated three times; the bacteria were counted and converted to a mean, which was used as the initial count on each surface.

Transfer rate of pathogen from contaminated meats to gloved hands and utensil The transfer rate was analyzed at meat processing plants. To evaluate the transfer of pathogens from contaminated meats to either polyethylene gloves or cotton gloved hands and utensils, the bacterial suspension (6 $\log _{10} \mathrm{CFU} / \mathrm{g}$ ) was inoculated onto the meats and allowed to dry. The workers picked up the meats with both hands and cut the sample for $10 \mathrm{~s}$ using a knife and cutting board. Next, the workers' polyethylene gloves or cotton gloves were sampled by crushing in $225 \mathrm{~g}$ buffered peptone water for $1 \mathrm{~min}$, and the knife and cutting board surfaces were sampled with a PBS swab. The swabbed area included the area in contact with the meat samples $(10 \times 10 \mathrm{~cm})$. Each swab was incubated in buffered peptone water for $5 \mathrm{~min}$ and mixed by vortexing for $1 \mathrm{~min}$, followed by analysis as described in the culture conditions section. All experiments were repeated three times.

\section{Transfer rate of pathogens from gloved hands to meat samples and utensils}

At the meat processing plants, the transfer rate of bacteria was analyzed between contaminated gloves, meat, and utensils. The bacterial suspension ( $\left.6 \log _{10} \mathrm{CFU} / \mathrm{g}\right)$ was inoculated onto the gloved hands of each worker and allowed to dry. The worker picked up the meat with both hands and cut the meat for $10 \mathrm{~s}$ using a knife and cutting board. At the end of the procedure, the meat was sampled by crushing in $225 \mathrm{~g}$ buffered peptone water for $1 \mathrm{~min}$, and the knife and cutting board surface were sampled by a PBS swab (3M pipette swab, St. Paul, MN, USA). The swabbed area included the area in contact with the meat samples $(10 \times 10 \mathrm{~cm})$. Each swab was incubated in buffered peptone water for $5 \mathrm{~min}$ and mixed by vortexing for $1 \mathrm{~min}$. The assay was performed as described in the culture conditions section. All experiments were repeated three times.

\section{Transfer rate}

Three samples for each surface and each treatment were evaluated, and a mean value was calculated. The transfer rate was determined as the ratio of the number of adherent bacteria to the initial bacterial count. The transfer rate (\%) was calculated as (CFU on destination / CFU on source) $\times 100$ $[20,21]$. Analysis of one factor with repeated measures and three replicates for each set of experi- 
mental parameters was conducted (SPSS 10.0, Chicago, IL, USA). Analysis of variance was used to determine the differences between sample means. Multiple comparisons among means were performed using the Duncan's test, with $p<0.05$ used as the significance level.

The transfer rate was determined as follows:

$$
\text { Transfer rate }(\%)=\frac{\text { CFU on destination }}{\text { CFU on source }} \times 100
$$

\section{Contamination levels in meat and utensils under butchering conditions over time}

This experiment was conducted to determine the duration of use of gloves during general butchering. Pieces of pork tenderloin were purchased from a butcher, and the transported pork was stored in a refrigerator. The cutting board and knife were cleaned with antibacterial soap for $30 \mathrm{~s}$, rinsed with distilled water for $15 \mathrm{~s}$, and then wiped with a paper towel and sterilized. The gloves (cotton, polyethylene) were sprayed with $70 \%$ ethanol, and the gloves, knife, and cutting board were examined under UV light on a clean bench for $1 \mathrm{~h}$. Experiments were conducted at $15^{\circ} \mathrm{C}$ to recreate the environment in the butcher's shop, and seven experiments were conducted for up to $10 \mathrm{~h}$. The "pre-experiment" included measuring the rate of contamination of the meat and utensils before cutting the pork, and "right after" includes measuring the rate of contamination in a sample of pork 5 min working after obtaining the pre-experiment microorganisms. Similarly, samples were analyzed after $1,2,4,8$, and $10 \mathrm{~h}$ after 5 min of working. Before each experiment, the gloves were sprayed twice with $70 \%$ ethanol and dried for $5 \mathrm{~s}$. The meat was cut with a knife on the cutting board for approximately $1 \mathrm{~min}$; the gloves, cutting board, and knife were sampled using the SWAB method (3M pipette swab). Next, $25 \mathrm{~g}$ of meat in $225 \mathrm{~mL}$ of sterilized physiological saline was crushed at $300 \mathrm{rpm}$ for $15 \mathrm{~min}$ using a stomacher (Seward). The plate counts of total bacteria, E. coli, and Salmonella spp. were measured using PCA medium, EMB medium, and XLD medium, respectively, according to the guidelines provided in the Korean Food Standards Codex [22]. All experiments were repeated three times.

\section{RESULTS AND DISCUSSION}

\section{Transfer rate from contaminated meat to gloves and utensils}

All workers at meat processing shops use cotton gloves, polyethylene gloves, or bare hands when handling meat. Particularly, cotton gloves help prevent the hands from slipping on raw meat. However, the consequences of wearing cotton gloves on hygiene are uncertain, as with few exceptions, published reports describe only the effects of wearing latex or polyethylene gloves during medical procedures or when serving food [23,24]. Meat processing shops have not established detailed regulations regarding the use of utensils and gloves. Therefore, we analyzed the cross-contamination of meat under various conditions. Table 1 summarizes the transfer rates from contaminated meat to cutting boards, knives, polyethylene gloves, and cotton gloves. The initial populations of $E$. coli, $S$. aureus, Sal. enterica subsp. enterica, and L. monocytogenes on raw meat were approximately 5-6 $\log _{10}$ CFU/g. After working with the contaminated meat, the population of pathogens on the cotton gloves (transfer rate 8.98\%-15.79\%) was monitored for E. coli, S. aureus, Sal. enterica, and L. monocytogenes, which showed values of 4.75, 4.48, 4.86, and $4.79 \log _{10} \mathrm{CFU} / \mathrm{g}$, respectively; these values on polyethylene gloves (transfer rate $0.24 \%-1.28 \%$ ) were $3.07,3.30,3.97$, and $3.55 \log _{10} \mathrm{CFU} / \mathrm{g}$. These observations indicate that bacteria are easily transferred from contaminated meats to gloves and utensils, particularly when cotton gloves are used. The relatively-high water absorption of cotton gloves may influence the transfer rate. Cotton is a hydrophilic surface and thus can promote the 


\begin{tabular}{|c|c|c|c|c|c|}
\hline \multirow{2}{*}{ Glove type } & \multirow{2}{*}{ Microbial strain } & \multirow{2}{*}{$\begin{array}{c}\text { Contamination source } \\
\text { Initial inoculated to pork meats }\end{array}$} & \multicolumn{3}{|c|}{ Transfer destination } \\
\hline & & & Cutting board & Knife & Glove \\
\hline \multirow[t]{4}{*}{ Cotton gloves } & Escherichia coli & $\begin{array}{l}5.69 \pm 0.02 \\
(100)\end{array}$ & $\begin{array}{l}3.50 \pm 0.03 \\
(0.64 \pm 0.05)^{\mathrm{Bbc}}\end{array}$ & $\begin{array}{l}3.37 \pm 0.02 \\
(0.51 \pm 0.05)^{\mathrm{BC}}\end{array}$ & $\begin{array}{c}4.75 \pm 0.01 \\
(11.37 \pm 0.15)^{\mathrm{Ab}}\end{array}$ \\
\hline & Staphylococcus aureus & $\begin{array}{l}5.27 \pm 0.03 \\
\quad(100)\end{array}$ & $\begin{array}{l}3.07 \pm 0.06 \\
(0.63 \pm 0.09)^{\mathrm{Bbc}}\end{array}$ & $\begin{array}{c}3.29 \pm 0.04 \\
(1.06 \pm 0.12)^{\mathrm{Bb}}\end{array}$ & $\begin{array}{c}4.48 \pm 0.02 \\
(15.79 \pm 0.79)^{\mathrm{Aa}}\end{array}$ \\
\hline & Salmonella enteritidis & $\begin{array}{l}5.90 \pm 0.02 \\
(100)\end{array}$ & $\begin{array}{l}3.37 \pm 0.06 \\
(0.97 \pm 0.14)^{\mathrm{Ba}}\end{array}$ & $\begin{array}{l}3.36 \pm 0.02 \\
(0.30 \pm 0.02)^{\mathrm{Cc}}\end{array}$ & $\begin{array}{c}4.86 \pm 0.01 \\
(8.98 \pm 0.29)^{\mathrm{AC}}\end{array}$ \\
\hline & Listeria monocytogenes & $\begin{array}{l}5.65 \pm 0.03 \\
\quad(100)\end{array}$ & $\begin{array}{l}3.49 \pm 0.09 \\
(0.71 \pm 0.20)^{\mathrm{Bb}}\end{array}$ & $\begin{array}{l}3.92 \pm 0.09 \\
(1.91 \pm 0.44)^{\mathrm{Ba}}\end{array}$ & $\begin{array}{c}4.79 \pm 0.09 \\
(12.25 \pm 1.32)^{\mathrm{Ab}}\end{array}$ \\
\hline \multirow[t]{4}{*}{ Polyethylene glove } & Escherichia coli & $\begin{array}{l}5.69 \pm 0.03 \\
(100)\end{array}$ & $\begin{array}{l}3.46 \pm 0.02 \\
(0.58 \pm 0.03)^{\mathrm{Abc}}\end{array}$ & $\begin{array}{l}3.29 \pm 0.01 \\
(0.40 \pm 0.02)^{B C}\end{array}$ & $\begin{array}{l}3.07 \pm 0.05 \\
(0.24 \pm 0.03)^{C d}\end{array}$ \\
\hline & Staphylococcus aureus & $\begin{array}{l}5.38 \pm 0.06 \\
(100)\end{array}$ & $\begin{array}{l}3.12 \pm 0.13 \\
(0.60 \pm 0.20)^{\mathrm{Abc}}\end{array}$ & $\begin{array}{l}3.33 \pm 0.02 \\
(0.83 \pm 0.08)^{A b}\end{array}$ & $\begin{array}{l}3.30 \pm 0.03 \\
(0.83 \pm 0.06)^{\mathrm{Ad}}\end{array}$ \\
\hline & Salmonella enteritidis & $\begin{array}{l}5.86 \pm 0.02 \\
(100)\end{array}$ & $\begin{array}{l}3.75 \pm 0.03 \\
(0.76 \pm 0.05)^{\mathrm{Bab}}\end{array}$ & $\begin{array}{l}3.23 \pm 0.12 \\
(0.26 \pm 0.05)^{\mathrm{Cc}}\end{array}$ & $\begin{array}{c}3.97 \pm 0.02 \\
(1.28 \pm 0.05)^{\mathrm{Ad}}\end{array}$ \\
\hline & Listeria monocytogenes & $\begin{array}{l}5.83 \pm 0.04 \\
(100)\end{array}$ & $\begin{array}{l}3.44 \pm 0.07 \\
(0.41 \pm 0.09)^{\mathrm{ABC}}\end{array}$ & $\begin{array}{l}3.20 \pm 0.13 \\
(0.24 \pm 0.10)^{\mathrm{BC}}\end{array}$ & $\begin{array}{l}3.55 \pm 0.15 \\
(0.52 \pm 0.15)^{\mathrm{Ad}}\end{array}$ \\
\hline
\end{tabular}

All values are mean \pm SD of three replicates.

${ }^{A-C}$ For the same row, alphabets indicate significant difference $(p<0.05)$ (Duncan's multiple $t$-test).

${ }^{a-d}$ For the small letters within columns significant difference and $(p<0.05)$ (Duncan's multiple $t$-test).

Transfer rate is expressed as the microbial reduction rate (\%).

transfer of pathogens to high-moisture surfaces, such as pork meat.

On cotton gloves, after the workers cut the contaminated meat, the populations of E. coli, S. aureus, Sal. enterica, and L. monocytogenes associated with the cutting board (transfer rate $0.63 \%-0.97 \%$ ) and knife (transfer rate $0.30 \%-1.91 \%$ ) were 3.50, 3.07, 3.37, and 3.49 and 3.37, 3.29, 3.36, and 3.92 $\log _{10} \mathrm{CFU} / g$, respectively. When polyethylene gloves were used, after cutting the contaminated meat, the E. coli, S. aureus, Sal. enterica, and L. monocytogene populations retrieved from the cutting board (transfer rate $0.41 \%-0.76 \%$ ) and knife (transfer rate $0.24 \%-0.83 \%$ ) were $3.46,3.12,3.75$, and 3.44 and 3.29, 3.33, 3.23, and 3.20 $\log _{10} \mathrm{CFU} / g$, respectively. For knives and cutting boards, the transfer rate was highest when processing involved cotton gloves rather than polyethylene gloves $(p$ $<0.05)$. Polyethylene gloves do not absorb bacteria quickly, and thus do not continuously contaminate meat unlike cotton gloves. Our results are similar to those of Kim et al. [21] who reported that the transfer rates of L. monocytogenes from contaminated pork meat were greater when cotton gloves were worn than when bare hands and polyethylene gloves were used. Additionally, Montville and Schaffner [25] observed low cross-contamination rates when using polyethylene gloves, and, Gill and Jones [23] reported that thick rubber gloves prevented the transfer of E. coli.

\section{Transfer rate of pathogens from gloved hands to meat samples and utensils}

The transfer rates from contaminated cotton gloves and contaminated polyethylene gloves to contact meat, and utensils are presented in Table 2. The initial population of pathogen on the glove was approximately $6 \log _{10} \mathrm{CFU} / \mathrm{g}$. For workers using contaminated cotton gloves, the populations of E. coli, S. aureus, Sal. enteritidis, and L. monocytogenes associated with the cutting board, knife, and meat were 3.50, 3.96, 3.46, and 3.75 $\log _{10} \mathrm{CFU} / \mathrm{g}$ (cutting board); 4.06, 3.81, 3.62, and 3.37 $\log _{10}$ $\mathrm{CFU} / \mathrm{g}$ (knife); and 3.73, 4.00, 3.85, and $3.55 \mathrm{Log}_{10} \mathrm{CFU} / \mathrm{g}$, respectively. Thus, the transfer rates were $0.07 \%-0.17 \%$ for cutting boards, $0.07 \%-0.54 \%$ for knives, and $0.10 \%-0.25 \%$ for meat. For workers using contaminated polyethylene gloves, E. coli, S. aureus, Sal. enteritidis, and L. monocytogenes associated with cutting board, knife and meat were 2.70, 2.47, 2.79, and $3.40 \log _{10} \mathrm{CFU} / \mathrm{g}$ (cutting board, transfer rate 0.02\%-0.06\%); 3.33, 2.35, 2.01, and $3.98 \log _{10}$ CFU/g (knife, transfer 


\begin{tabular}{|c|c|c|c|c|c|}
\hline \multirow{2}{*}{ Glove type } & \multirow{2}{*}{ Microbial strain } & \multirow{2}{*}{$\frac{\text { Contamination source }}{\text { Initial inoculated to wearing gloves }}$} & \multicolumn{3}{|c|}{ Transfer destination } \\
\hline & & & Cutting board & Knife & Meat \\
\hline \multirow[t]{4}{*}{ Cotton gloves } & Escherichia coli & $\begin{array}{c}6.33 \pm 0.04 \\
(100)\end{array}$ & $\begin{array}{l}3.50 \pm 0.03 \\
(0.15 \pm 0.01)^{\mathrm{Ca}}\end{array}$ & $\begin{array}{l}4.06 \pm 0.06 \\
(0.54 \pm 0.07)^{\mathrm{Aa}}\end{array}$ & $\begin{array}{l}3.73 \pm 0.02 \\
(0.25 \pm 0.01)^{\mathrm{Ba}}\end{array}$ \\
\hline & Staphylococcus aureus & $\begin{array}{l}6.84 \pm 0.03 \\
(100)\end{array}$ & $\begin{array}{l}3.96 \pm 0.05 \\
(0.13 \pm 0.02)^{\text {Bab }}\end{array}$ & $\begin{array}{l}3.81 \pm 0.06 \\
(0.09 \pm 0.02)^{\mathrm{Ccd}}\end{array}$ & $\begin{array}{l}4.00 \pm 0.08 \\
(0.14 \pm 0.03)^{A C}\end{array}$ \\
\hline & Salmonella enteritidis & $\begin{array}{c}6.61 \pm 0.07 \\
(100)\end{array}$ & $\begin{array}{l}3.46 \pm 0.03 \\
(0.07 \pm 0.01)^{\mathrm{Bbc}}\end{array}$ & $\begin{array}{l}3.62 \pm 0.08 \\
(0.11 \pm 0.04)^{\mathrm{Cbc}}\end{array}$ & $\begin{array}{l}3.85 \pm 0.02 \\
(0.18 \pm 0.01)^{\mathrm{Ab}}\end{array}$ \\
\hline & Listeria monocytogenes & $\begin{array}{l}6.55 \pm 0.05 \\
(100)\end{array}$ & $\begin{array}{l}3.75 \pm 0.16 \\
(0.17 \pm 0.08)^{\mathrm{Aa}}\end{array}$ & $\begin{array}{l}3.37 \pm 0.10 \\
(0.07 \pm 0.02)^{\text {Acde }}\end{array}$ & $\begin{array}{l}3.55 \pm 0.15 \\
(0.10 \pm 0.04)^{\mathrm{AC}}\end{array}$ \\
\hline \multirow[t]{4}{*}{ Polyethylene glove } & Escherichia coli & $\begin{array}{l}6.09 \pm 0.02 \\
(100)\end{array}$ & $\begin{array}{l}2.70 \pm 0.04 \\
(0.04 \pm 0.01)^{\mathrm{Bc}}\end{array}$ & $\begin{array}{l}3.33 \pm 0.04 \\
(0.18 \pm 0.02)^{\mathrm{Ab}}\end{array}$ & $\begin{array}{l}2.77 \pm 0.02 \\
(0.02 \pm 0.01)^{\mathrm{Cd}}\end{array}$ \\
\hline & Staphylococcus aureus & $\begin{array}{l}6.34 \pm 0.01 \\
(100)\end{array}$ & $\begin{array}{l}2.47 \pm 0.03 \\
(0.06 \pm 0.07)^{\mathrm{AC}}\end{array}$ & $\begin{array}{l}2.35 \pm 0.04 \\
(0.01 \pm 0.01)^{\mathrm{Ae}}\end{array}$ & $\begin{array}{l}2.40 \pm 0.07 \\
(0.01 \pm 0.01)^{\mathrm{Ad}}\end{array}$ \\
\hline & Salmonella enteritidis & $\begin{array}{l}6.48 \pm 0.02 \\
(100)\end{array}$ & $\begin{array}{l}2.79 \pm 0.01 \\
(0.02 \pm 0.01)^{\mathrm{BC}}\end{array}$ & $\begin{array}{l}2.01 \pm 0.06 \\
(0.03 \pm 0.01)^{\mathrm{Cde}}\end{array}$ & $\begin{array}{l}2.83 \pm 0.02 \\
(0.02 \pm 0.01)^{\mathrm{Ad}}\end{array}$ \\
\hline & Listeria monocytogenes & $\begin{array}{l}6.75 \pm 0.04 \\
(100)\end{array}$ & $\begin{array}{l}3.40 \pm 0.11 \\
(0.05 \pm 0.02)^{\mathrm{BC}}\end{array}$ & $\begin{array}{l}3.98 \pm 0.06 \\
(0.17 \pm 0.04)^{\mathrm{Ab}}\end{array}$ & $\begin{array}{l}2.93 \pm 0.04 \\
(0.01 \pm 0.01)^{\mathrm{Bd}}\end{array}$ \\
\hline
\end{tabular}

All values are mean \pm SD of three replicates.

${ }^{A-C}$ For the same row, alphabets indicate significant difference $(p<0.05)$ (Duncan's multiple $t$-test).

${ }^{a-e}$ For the small letters within columns significant difference and $(p<0.05)$ (Duncan's multiple $t$-test).

Transfer rate is expressed as the microbial reduction rate (\%).

rate $0.01 \%-0.18 \%$ ); and 2.77, 2.40, 2.83, and 2.93 $\log _{10} \mathrm{CFU/g}$ (meat, transfer rate 0.01\%-0.02\%), respectively. Similar to the results shown in Table 1, these findings indicate that the transfer rate for cotton gloves was significantly greater than that for polyethylene gloves $(p<0.05)$. This is also related to the moisture-retaining ability of cotton gloves during work, whereas polyethylene gloves protect against cross contamination. Additionally, the rate of cross-contamination differed depending on the cutting board, knife, and bacteria. The highest transfer rate was observed for knives as compared to that for cutting boards and meat. Although the underlying reason is not clear, these results may depend on the workhouse environment [26]. Ravishankar et al. [20] reported that the bacterial transfer rate from contaminated chickens to cutting boards was $1.25 \%$ and from chickens to knives was $0.05 \%$, reflecting the larger surface area of the cutting boards causing direct exposure. Understanding the factors that lead to contamination of meat products destined for consumption by humans is important for preventing the spread of pathogenic bacteria and foodborne illnesses [27]. As shown in Tables 1 and 2, the transfer rate of bacteria from contaminated gloves to meat or utensils was lower than that from contaminated meat to glove or utensils $(p<0.05)$. These results are similar to those of Jimenez et al. [28] who showed that the transfer rate of Salmonella spp. from gloves to green bell peppers was lower than that from green bell peppers to gloves. Thus, the moisture content of pork meat commodities may facilitate detachment of pathogens from the cutting boards and knives by more than from gloves.

\section{Analysis of microbial levels in meat and on utensils under butchering conditions}

Table 3 shows microbial contamination under general butchering conditions when wearing cotton gloves. During $10 \mathrm{~h}$ of work, bacteria colonies were detected on the meat (5.44 $\log _{10} \mathrm{CFU} /$ g) and tools (3.37 $\log _{10} \mathrm{CFU} / \mathrm{g}$ ), although E. coli and Salmonella spp. were not detected. However, the bacterial counts associated with all tools did not exceed the HACCP standard [16]. This result is similar to those of Hilton and Austin [29], who did not detect Salmonella spp. in experiments involving a dishcloth made of a material similar to that used in cotton gloves [21]. Therefore, we predict that safety and compliance with HACCP standards can be maintained if the workers 


\begin{tabular}{|c|c|c|c|c|c|c|c|c|}
\hline Medium & Microbial strain & Pre-experiment & Right after & After $1 \mathrm{~h}$ & After $2 \mathrm{~h}$ & After $4 \mathrm{~h}$ & After $8 \mathrm{~h}$ & After $10 \mathrm{~h}$ \\
\hline \multirow[t]{5}{*}{ Cotton gloves } & Plate count bacteria & $N D^{c}$ & $2.15 \pm 0.15^{b}$ & $2.93 \pm 0.15^{\mathrm{a}}$ & $3.39 \pm 0.49^{a}$ & $3.16 \pm 0.56^{a}$ & $3.10 \pm 0.40^{\mathrm{a}}$ & $3.09 \pm 0.62^{a}$ \\
\hline & Escherichia coli & ND & ND & ND & ND & ND & ND & ND \\
\hline & Staphylococcus aureus & ND & ND & ND & ND & ND & ND & ND \\
\hline & Salmonella spp. & ND & ND & ND & ND & ND & ND & ND \\
\hline & Listeria monocytogenes & ND & ND & ND & ND & ND & ND & ND \\
\hline \multirow[t]{5}{*}{ Cutting board } & Plate count bacteria & $N D^{b}$ & $2.95 \pm 0.48^{\mathrm{a}}$ & $3.23 \pm 0.53^{\mathrm{a}}$ & $3.12 \pm 0.52^{\mathrm{a}}$ & $3.37 \pm 0.37^{\mathrm{a}}$ & $3.29 \pm 0.33^{\mathrm{a}}$ & $3.27 \pm 0.22^{\mathrm{a}}$ \\
\hline & Escherichia coli & ND & ND & ND & ND & ND & ND & ND \\
\hline & Staphylococcus aureus & ND & ND & ND & ND & ND & ND & ND \\
\hline & Salmonella spp. & ND & ND & ND & ND & ND & ND & ND \\
\hline & Listeria monocytogenes & ND & ND & ND & ND & ND & ND & ND \\
\hline \multirow[t]{5}{*}{ Knife } & Plate count bacteria & $N D^{c}$ & $2.07 \pm 0.07^{b}$ & $2.71 \pm 0.71^{\mathrm{ab}}$ & $2.57 \pm 0.27^{\mathrm{ab}}$ & $2.91 \pm 0.61^{a}$ & $3.10 \pm 0.40^{\mathrm{a}}$ & $2.94 \pm 0.46^{a}$ \\
\hline & Escherichia coli & ND & ND & ND & ND & ND & ND & ND \\
\hline & Staphylococcus aureus & ND & ND & ND & ND & ND & ND & ND \\
\hline & Salmonella spp. & ND & ND & ND & ND & ND & ND & ND \\
\hline & Listeria monocytogenes & ND & ND & ND & ND & ND & ND & ND \\
\hline \multirow[t]{5}{*}{ Meat } & Plate count bacteria & $4.40 \pm 0.04^{c}$ & $5.13 \pm 0.13^{\mathrm{b}}$ & $5.44 \pm 0.01^{\mathrm{a}}$ & $5.08 \pm 0.04^{\mathrm{b}}$ & $5.06 \pm 0.06^{\mathrm{b}}$ & $5.09 \pm 0.05^{b}$ & $5.11 \pm 0.07^{b}$ \\
\hline & Escherichia coli & ND & ND & ND & ND & ND & ND & ND \\
\hline & Staphylococcus aureus & ND & ND & ND & ND & ND & ND & ND \\
\hline & Salmonella spp. & ND & ND & ND & ND & ND & ND & ND \\
\hline & Listeria monocytogenes & ND & ND & ND & ND & ND & ND & ND \\
\hline
\end{tabular}

All values are mean \pm SD of three replicates.

${ }^{a-c}$ For the same row, alphabets indicate significant difference $(p<0.05)$ (Duncan's multiple $t$-test).

ND, not detected.

are required to wear cotton gloves for $10 \mathrm{~h}$ per day, provided that $70 \%$ ethanol is sprayed on the gloves at the end of each round of cutting. The results of microbial contamination analysis while wearing polyethylene gloves are shown in Table 4. Bacteria were not detected after $10 \mathrm{~h}$ on the polyethylene gloves, cutting board, or knife. Plate count bacteria were detected in the meat in the range of 4.09-5.07 $\log _{10}$ CFU/g; E. coli, S. aureus, Sal. spp., and L. monocytogens were not detected on either the tools or meat. All utensils was could be used for up to $10 \mathrm{~h}$, as the bacterial counts were below the standards prescribed by the HACCP. Comparison of the results shown in Tables 3 and 4 revealed that contamination of utensils with general bacteria was significantly lower when polyethylene gloves were used rather than cotton gloves. The growth rate of microorganisms may be lower on latex gloves, as significant changes were not observed. This is because of differences in the material and the hydrophobic properties of cotton gloves and polyethylene gloves. Therefore, our results show that using polyethylene gloves rather than cotton gloves may effectively reduce cross-contamination during meat processing. Moore et al. [30] showed that the differences in material and the hydrophobic properties of cotton gloves and latex gloves affect microbial transfer associated with cross contamination. In contrast to our results, Robinson et al. [31] suggested that gloves cannot prevent high levels of microbial contamination; thus, it would be desirable to replace gloves frequently considering the condition of the meat and frequency of tool use [32]. In summary, our study provides important information regarding meat-plant hygiene and the transfer efficiency of pathogenic bacteria during meat processing. Further, our results may be helpful for related industries, as improving the processing of meat products will increase consumer confidence and decrease the incidence of food-related illnesses. Further studies are needed to determine the cross-contam- 


\begin{tabular}{|c|c|c|c|c|c|c|c|c|}
\hline Medium & Microbial strain & Pre-experiment & Right after & After $1 \mathrm{~h}$ & After $2 \mathrm{~h}$ & After $4 \mathrm{~h}$ & After $8 \mathrm{~h}$ & After $10 \mathrm{~h}$ \\
\hline \multirow[t]{5}{*}{ Latex gloves } & Plate count bacteria & ND & ND & ND & ND & ND & ND & ND \\
\hline & Escherichia coli & ND & ND & ND & ND & ND & ND & ND \\
\hline & Staphylococcus aureus & ND & ND & ND & ND & ND & ND & ND \\
\hline & Salmonella spp. & ND & ND & ND & ND & ND & ND & ND \\
\hline & Listeria monocytogenes & ND & ND & ND & ND & ND & ND & ND \\
\hline \multirow[t]{5}{*}{ Cutting board } & Plate count bacteria & ND & ND & ND & ND & ND & ND & ND \\
\hline & Escherichia coli & ND & ND & ND & ND & ND & ND & ND \\
\hline & Staphylococcus aureus & ND & ND & ND & ND & ND & ND & ND \\
\hline & Salmonella spp. & ND & ND & ND & ND & ND & ND & ND \\
\hline & Listeria monocytogenes & ND & ND & ND & ND & ND & ND & ND \\
\hline \multirow[t]{5}{*}{ Knife } & Plate count bacteria & ND & ND & ND & ND & ND & ND & ND \\
\hline & Escherichia coli & ND & ND & ND & ND & ND & ND & ND \\
\hline & Staphylococcus aureus & ND & ND & ND & ND & ND & ND & ND \\
\hline & Salmonella spp. & ND & ND & ND & ND & ND & ND & ND \\
\hline & Listeria monocytogenes & ND & ND & ND & ND & ND & ND & ND \\
\hline \multirow[t]{5}{*}{ Meat } & Plate count bacteria & $5.07 \pm 0.16^{a}$ & $4.86 \pm 0.14^{b}$ & $4.36 \pm 0.06^{c}$ & $4.76 \pm 0.03^{b}$ & $4.10 \pm 0.10^{d}$ & $4.09 \pm 0.05^{d}$ & $4.43 \pm 0.03^{c}$ \\
\hline & Escherichia coli & ND & ND & ND & ND & ND & ND & ND \\
\hline & Staphylococcus aureus & ND & ND & ND & ND & ND & ND & ND \\
\hline & Salmonella spp. & ND & ND & ND & ND & ND & ND & ND \\
\hline & Listeria monocytogenes & ND & ND & ND & $\mathrm{ND}$ & ND & ND & ND \\
\hline
\end{tabular}

All values are mean \pm SD of three replicates.

${ }^{a-d}$ For the same row, alphabets indicate significant difference $(p<0.05)$ (Duncan's multiple $t$-test).

ND, not detected.

ination rate while considering more process-specific parameters than actual work processes about removal of microorganisms.

\section{REFERENCES}

1. Lee JK, Kim EH, Lee MA. Consumer hygiene practices regarding the use of home refrigerators to store meat in the capital area of Korea. Korean J Food Sci Anim Resour. 2013;33:14954. https://doi.org/10.5851/kosfa.2013.33.2.149

2. An KA, Jo Y, Arshad MS, Kim GR, Jo C, Kwon JH. Assessment of microbial and radioactive contaminations in Korean cold duck meats and electron-beam application for quality improvement. Korean J Food Sci Anim Resour. 2017;37:297-304. https://doi.org/10.5851/kosfa.2017.37.2.297

3. Bean NH, Griffin PM. Foodborne disease outbreaks in the United States, 1973-1987: pathogens, vehicles, and trends. J Food Prot. 1990;53:804-17. https://doi.org/10.4315/0362028X-53.9.804

4. Brashears MM, Galyean ML, Loneragan GH, Mann JE, Killinger-Mann K. Prevalence of Escherichia coli O157: H7 and performance by beef feedlot cattle given Lactobacillus directfed microbials. J Food Prot. 2003;66:748-54. https://doi.org/10.4315/0362-028X-66.5.748

5. Cha JH. A study of consumption pattern of beef and pork-focused on Kwangju citizens [Master's thesis]. Gwangju, Korea: Chonnam National University; 2007.

6. Kim HJ, Griffiths MW, Fazil AM, Lammerding AM. Probabilistic risk model for Staphy- 
lococcal intoxication from pork-based food dishes prepared in food service establishments in Korea.J Food Prot. 2009;72:1897-908. https://doi.org/10.4315/0362-028X-72.9.1897

7. Kitai S, Shimizu A, Kawano J, Sato E, Nakano C, Kitagawa H, et al. Prevalence and characterization of Staphylococcus aureus and enterotoxigenic Staphylococcus aureus in retail raw chicken meat throughout Japan. J Vet Med Sci. 2005;67:269-74. https://doi.org/10.1292/ jvms.67.269

8. Lee JY, Paik JK, Hwang HS, Lee JE, Shin WS, Kim HW, et al. Survey of hygienic condition and management of meat markets in Seoul and Gyeong-Gi area, Korea. Korean J Food Sci Anim Resour. 2010;30:336-44. https://doi.org/10.5851/kosfa.2010.30.2.336

9. Zhao P, Zhao T, Doyle MP, Rubino JR, Meng J. Development of a model for evaluation of microbial cross-contamination in the kitchen. J Food Prot. 1998;61:960-3. https://doi. org/10.4315/0362-028X-61.8.960

10. Chen Y, Jackson KM, Chea FP, Schaffner DW. Quantification and variability analysis of bacterial cross-contamination rates in common food service tasks. J Food Prot. 2001;64:72-80. https://doi.org/10.4315/0362-028X-64.1.72

11. Luppens SB, Reij MW, van der Heijden RW, Rombouts FM, Abee T. Development of a standard test to assess the resistance of Staphylococcus aureus biofilm cells to disinfectants. Appl Environ Microbiol. 2002;68:4194-200. https://doi.org/10.1128/AEM.68.9.4194-4200.2002

12. Oh MH, Park BY, Jo H, Lee S, Lee H, Choi KH, et al. Use of antimicrobial food additives as potential dipping solutions to control Pseudomonas spp. contamination in the frankfurters and ham. Korean J Food Sci Anim Resour. 2014;34:591-6. https://doi.org/10.5851/kosfa.2014.34.5.591

13. Bean NH, Goulding JS, Lao C, Angulo FJ. Surveillance for foodborne disease outbreaks United States, 1988-1992. Morb Mortal Wkly Rep. 1996;45:1-67.

14. Forsythe SJ, Hayes PR. Food hygiene, microbiology, and HACCP. Boston, MA: Springer; 2010. p. 1-449.

15. Kim JG, Park JY, Kim JS. A comparison of microbial load on bare and gloved hands among food handlers. J Environ Health Sci. 2011;37:298-305. https://doi.org/10.5668/ JEHS.2011.37.4.298

16. Korea Food Safety Management Certification Board. The meat trade HACCP management standard [Internet]. 2018 [cited 2020 Oct 20]. https:/www.haccp.or.kr/site/haccp/boardView. do?post=57299\&boardSeq=117\&key=164

17. Kim JH, Nam KC, Jo C, Lim DG. Perception of the HACCP system operators on livestock product manufacturers. J Anim Sci Technol. 2014;56:19-24. https://doi.org/10.1186/20550391-56-19

18. Ministry of Food and Drug Safety [Internet]. Food standards and specifications. 2020 [cited 2020 Oct 20]. https://foodsafetykorea.go.kr/foodcode/03_02.jsp?idx=37

19. Ministry of Food and Drug Safety [Internet]. Sterilization and disinfection test method. 2020 [cited 2020 Oct 20]. https://www.foodsafetykorea.go.kr/foodcode/04_03.jsp?idx=887

20. Ravishankar S, Zhu L, Jaroni D. Assessing the cross contamination and transfer rates of Salmonella enterica from chicken to lettuce under different food-handling scenarios. Food Microbiol. 2010;27:791-4. https://doi.org/10.1016/j.fm.2010.04.011

21. Kim SJ, Park MS, Bahk GK, Rahman SME, Park JH, Oh DH. Transfer rate of cross contamination of Listeria monocytogenes between pork meat and workers' hands during pork meat processing.J Food Hyg Saf. 2011;26:330-5.

22. Ministry of Food and Drug Safety. Food Code [Internet]. 2020. [cited 2020 Jan 14]. http:// www.foodsafetykorea.go.kr/foodcode/01_01.jsp 
23. Gill CO, Jones T. Effects of wearing knitted or rubber gloves on the transfer or Escherichia coli between hands and meat. J Food Prot. 2002;65:1045-8. https://doi.org/10.4315/0362028X-65.6.1045

24. Fendler EJ, Dolan MJ, Williams RA. Handwashing and gloving for food protection part I: examination of the evidence. Dairy Food Environ Sanit. 1998;18:814-23.

25. Montville R, Schaffner DW. Inoculum size influences bacterial cross contamination between surfaces. Appl Environ Microbiol. 2003;69:7188-93. https://doi.org/10.1128/ AEM.69.12.7188-7193.2003

26. Manios SG, Grivokostopoulos NC, Bikouli VC, Doultsos DA, Zilelidou EA, Gialitaki MA, et al. A 3-year hygiene and safety monitoring of a meat processing plant which uses raw materials of global origin. Int J Food Microbiol. 2015;209:60-9. https://doi.org/10.1016/j.ijfoodmicro.2014.12.028

27. Beuchat LR, Ryu JH. Produce handling and processing practices. Emerg Infect Dis. 1997;3:459-65. https://doi.org/10.3201/eid0304.970407

28. Jimenez M, Siller JH, Valdez JB, Carrillo A, Chaidez C. Bidirectional Salmonella enterica serovar Typhimurium transfer between bare/glove hands and green bell pepper and its interruption. Int J Environ Health Res. 2007;17:381-8. https://doi.org/10.1080/09603120701372664

29. Hilton AC, Austin E. The kitchen dishcloth as a source of and vehicle for foodborne pathogens in a domestic setting. Int J Environ Health Res. 2000;10:257-61. https://doi. org/10.1080/09603120050127202

30. Moore G, Dunnill CW, Wilson APR. The effect of glove material upon the transfer of methicillin-resistant Staphylococcus aureus to and from a gloved hand. Am J Infect Control. 2013;41:19-23. https://doi.org/10.1016/j.ajic.2012.03.017

31. Robinson AL, Lee HJ, Kwon JH, Todd E, Rodriguez FP, Ryu D. Adequate hand washing and glove use are necessary to reduce cross-contamination from hands with high bacterial loads. J Food Prot. 2016;79:304-8. https://doi.org/10.4315/0362-028X.JFP-15-342

32. Trampuz A, Widmer A. Hand hygiene: a frequently missed lifesaving opportunity during patient care. Mayo Clin Proc. 2004;79:109-16. https://doi.org/10.4065/79.1.109 